\title{
Are differences in FSH concentrations involved in the control of ovulation rate in Romanov and Ile-de-France ewes?
}

\author{
M. A. Driancourt, P. Philipon, A. Locatelli, E. Jacques* and R. Webb $†$ \\ I.N.R.A., Reproductive Physiology, 37380 Monnaie, France; ${ }^{*}$ Facultes N.D. de la Paix, \\ B 5000 Namur, Belgium; and $\dagger$ AFRC Institute of Animal Physiology and Genetics Research, \\ Edinburgh Research Station, Roslin, Midlothian EH25 9PS, U.K.
}

\begin{abstract}
Summary. Despite differences in FSH concentrations ranging from $1.5 \mathrm{ng} / \mathrm{ml}$ (Romanov ewes) to $4 \mathrm{ng} / \mathrm{ml}$ (Ile-de-France ewes) between the follicular and luteal phases, follicular growth (numbers of follicles growing, growth rates, maximum size reached) was morphologically similar between the two stages of the cycle. Injection of $750 \mathrm{i} . \mathrm{u}$. hCG at Day 6 or 16 of the cycle triggered ovulation of $4 \cdot 1 \pm 0 \cdot 7$ and $4 \cdot 0 \pm 1 \cdot 3$ follicles in Romanov and $2.2 \pm 0.5$ and $1.7 \pm 0.5$ follicles in Ile-de-France ewes, respectively, demonstrating that functional differentiation was similar between the two stages of the cycle. As gonadotrophin environment differs between these two stages of the cycle, this suggests that there is a wide flexibility in the amount of gonadotrophins required to trigger terminal follicular growth and that ovarian requirements for gonadotrophins might work through thresholds. When Romanov and Ile-de-France ewes were given similar amounts of exogenous gonadotrophins (1250 i.u. PMSG, 750 i.u. hCG) after hypophysectomy, ovulation rates were close to the usual values (Romanov, $5 \cdot 5 \pm 3 \cdot 9$; Ile-de-France, $1.4 \pm 0.5$ ), demonstrating that differences in gonadotrophin concentrations during the follicular phase do not play a major role in the high ovulation of the Romanov compared to the Ile-de-France ewes.
\end{abstract}

Keywords: FSH; ovulation rate; follicular growth; prolific ewes; stage of the cycle

\section{Introduction}

Growth of follicles $>2 \mathrm{~mm}$ diameter in sheep is acutely dependent on gonadotrophins (Dufour et al., 1979; McNeilly et al., 1986). However, the extent to which gonadotrophin concentrations contribute to the different number of follicles ovulating in breeds of different fecundity is still unclear. While there is general agreement that $\mathbf{L H}$ is not involved in the control of ovulation rate (McNatty et al., 1981a), discrepancies exist in the concentrations of FSH in prolific and nonprolific breeds of sheep. Prolific D'Man and Booroola ewes have been reported to have higher FSH concentrations during the follicular phase compared with their local controls (Lahlou-Kassi et al., 1984; Bindon et al., 1984). In contrast, studies undertaken in the two other prolific breeds of sheep (Romanov and Finnish Landrace) have either revealed a non-significant superiority in FSH values in the prolific Romanov ewes over the Ile-de-France controls (Cahill et al., 1981) or no difference when Finns were compared with Suffolk ewes with lower ovulation rate (Webb \& England, 1982). Furthermore, within a prolific breed, there was no significant correlation between ovulation rate and follicular-phase FSH concentrations (D'Man: Lahlou-Kassi, 1982; Booroola: Bindon et al., 1986; Romanov: M. A. Driancourt \& L. P. Cahill, unpublished results). This could mean that differences in FSH concentrations between some prolific breeds and their controls may only be an effect of the different number of ovulatory follicles rather than a cause of high ovulation rate. 
The aim of this work was to study whether there was a linear relationship between gonadotrophin concentrations and growth of large follicles towards ovulation. Therefore, in profile Romanov and non-prolific Ile-de-France ewes, follicular growth was compared during the luteal and follicular phases, two periods which differ markedly in their hormonal environment (Baird et al., 1976; Baird, 1978; Miller et al., 1981). Thereafter, the effect on ovulation rate of removing the endogenous gonadotrophins by hypophysectomy and giving similar amounts of exogenous gonadotrophins (PMSG and hCG) was examined.

\section{Materials and Methods}

Experiment I: within-breed comparison of follicular measures in Ile-de-France and Romanov ewes during the luteal and follicular phases of the oestrous cycle. During the mid-breeding season (November) the oestrous cycle of $12 \mathrm{Romanov}$ ( $2-4$ years old) and 12 Ile-de-France ( $2-4$ years old) ewes were synchronized by insertion of progestagen-impregnated vaginal sponges (40 mg fluorogestone acetate: Intervet, Angers, France) for 14 days. Starting $36 \mathrm{~h}$ after sponge removal, ewes were examined twice daily to determine the time of onset of oestrus (Day 0 ). The ewes were then randomized into two groups for study during the luteal and follicular phases of the oestrous cycle. Thereafter the 6 Ile-de-France and the 6 Romanov ewes of the luteal-phase group underwent repeated laparotomies under anaesthesia induced and maintained by a continuous flow of a mixture of alphaxalone and alphadolone acetate (Midatrene, ICI, Enghien, France) at Days 3, 5 and 7 of the cycle (Day 0 = oestrus) and were killed at Day 9. At each laparotomy, the 3 largest follicles of each ovary were measured and marked with dots of ink in the surrounding ovarian stroma (Driancourt \& Cahill, 1984). Previously labelled follicles were also measured. The 6 Ile-de-France and 6 Romanov ewes of the follicular-phase group underwent the same procedure at Days 13 and 15 of the cycle and after they were detected in oestrus (about Day 17). This procedure of ink labelling of follicles has been repeatedly shown not to interfere with the mechanisms controlling ovulation rate (Driancourt et al., 1985a, 1986). Starting on the night preceding the first laparotomy, all ewes were blood sampled three times per day $(08: 00,16: 00,24: 00 \mathrm{~h})$ until the end of the experiment for FSH measurement.

Experiment II: ovarian response to hCG, given during the luteal and follicular phases, in ewes of different prolificacy. During the early breeding season (October), the same ewes as in Exp. I were synchronized as for Exp. I. After randomization into luteal- or follicular-phase groups all animals were injected with 750 i.u. hCG (Chorulon: Intervet, Angers, France), given intramuscularly, at Day 6 (luteal phase) or Day 16 (follicular phase) of the cycle. Laparoscopic examination of the ovaries was conducted 2 days later to count the number of corpora lutea. In the luteal-phase group, young corpora lutea were distinguished from the older ones according to the criteria of Oldham \& Lindsay (1980).

Experiment III: between-breed comparison of the effect of hypophysectomy and exogenous gonadotrophins on ovulation rate. During the mid-breeding season (December), 6 Ile-de-France and 14 Romanov ewes were synchronized by a 14-day treatment with intravaginal sponges (Intervet). At sponge removal, all ewes were hypophysectomized by the technique of Denamur \& Mauléon (1963). Briefly, ewes under general anaesthesia $\left(\mathrm{O}_{2}\right.$ plus fluothane) and lying on their back had their pituitary removed using a parapharyngeal approach. An opening was made close to the hyoid bone and the sphenoid was perforated in order to reach the anterior side of the pituitary which was mechanically removed and replaced by surgical wax.

After recovery from surgery (usually $1 \mathrm{~h}$ ), the ewes were injected intramuscularly with 750 i.u. PMSG (Chronogest: Intervet). This was followed, $24 \mathrm{~h}$ later, with $500 \mathrm{i} . \mathrm{u}$. PMSG and $72 \mathrm{~h}$ after hypophysectomy with $750 \mathrm{i} . \mathrm{u}$. hCG (Chorulon: Intervet). All ewes were killed 3 days after hCG injection. During the time between hypophysectomy and slaughter, they received daily glucocorticoid replacement therapy ( $0.2 \mathrm{ml}$ Dexadreson/day: Intervet) and were blood sampled twice at the time of hCG injection and just before slaughter for the assay of prolactin concentrations to check the completeness of hypophysectomy.

Assays. FSH concentrations in Exp. 1 were measured using the homologous radioimmunoassay described by Blanc \& Poirier (1979). The results are expressed as ng HG FSH 225/ml which has a potency of $35 \times \mathrm{NIH-FSH-S3}$. All samples were measured in a single assay. Sensitivity is $0.25 \mathrm{ng} / \mathrm{ml}$ and within-assay coefficients of variation are $9 \%$ and $18 \%$, for concentrations of 10 and $4 \mathrm{ng} / \mathrm{ml}$ respectively. In an attempt to overcome the large between-ewe variations in FSH concentrations, three types of FSH patterns were defined according to the magnitude and the timing of the changes noticed: no feed back when there were no consistent changes in the FSH profile, early feed back when a drop exceeding $25 \%$ compared to the previous values was detected before the 4 th bleed, and late feed back when a similar drop occurred later (usually between the 7th and the 9th bleed). Each ewe was then ranked in one of these three patterns.

Prolactin was measured using the homologous radioimmunoassay of Kann (1971) in the samples from Exp. III to check that hypophysectomy was complete. The results are expressed as ng NIH-P-S6/mi. All samples were measured in a single assay. The sensitivity of the assay was $0.3 \mathrm{ng} / \mathrm{ml}$ and the within-assay coefficient of variation was $15 \%$. 
Statistical methods. For each breed, the FSH concentrations measured in Exp. 1 were compared by a two-way analysis of variance that takes into account repeated measures on the same animal to detect the effect of the stage of the cycle and of the sample number within stages as described by Gill \& Hafs (1971). The stage of the cycle effects were tested against the between ewe mean squares. Follicle numbers and growth rates were compared using the Mann and Whitney U test (Siegel, 1956).

\section{Results}

\section{Experiment I}

Follicular growth in Romanov ewes. There was no difference between stages of the cycle in the number of follicles growing between the first two laparotomies (Days 3-5 and Days 13-15) or between the next two laparotomies (Days 5-7 and 15-17). Follicular loss through atresia at the time of selection (i.e. the ratio of the number of follicles growing between the second and third laparotomies to the number of follicles growing between the first and second laparotomies) was also similar between stages of the cycle (Table 1).

Table 1. Patterns of follicular growth in two breeds of sheep at two stages of the cycle

\begin{tabular}{lcccc}
\hline & $\begin{array}{c}\text { No. of growing } \\
\text { follicles between } \\
\text { the first } 2 \\
\text { laparotomies }\end{array}$ & $\begin{array}{c}\text { No. of growing } \\
\text { follicles between } \\
\text { the last } 2 \\
\text { laparotomies }\end{array}$ & $\begin{array}{c}\text { \% of recruited } \\
\text { follicles not } \\
\text { regressing }\end{array}$ \\
\hline Romanov & $\begin{array}{c}\text { Follicular phase } \\
(\mathrm{N}=6) \\
\text { Luteal phase } \\
(\mathrm{N}=6)\end{array}$ & $6.3 \pm 1.7$ & $3.7 \pm 1.4$ & $59 \pm 19$ \\
$\begin{array}{c}\text { Follicular phase } \\
(\mathrm{N}=6) \\
\text { Luteal phase } \\
(\mathrm{N}=6)\end{array}$ & $6.3 \pm 2.5$ & $3.5 \pm 1.0$ & $61 \pm 24$ \\
\hline
\end{tabular}

Values are mean \pm s.d.

Values with different superscripts differ $(P<0.05)$.

In contrast to the lack of effect of the stage of the cycle on the pattern of follicular growth, there were differences in the sizes and rates of follicular enlargement of the follicles monitored through the repeated laparotomies (Table 2). At the first laparotomy, the follicles growing later were smaller during the luteal phase and grew faster between the first two laparotomies.

However, the size of the marked and growing follicles at the second and third laparotomies, as well as their growth rates, were similar between Days 5-7 and 15-17. Also the maximum size of follicles reached during the luteal phase was similar to the preovulatory size.

Follicular growt in Ile-de-France ewes. Again, there was very little difference between the follicular and luteal phases in the pattern of terminal follicular growth. The number of follicles involved, their sizes at the successive laparotomies and their growth rates were unaffected by the stage of the oestrous cycle (Tables 1 and 2).

FSH concentrations. As shown in Fig. 1, in Ile-de-France ewes there was a significant stage of the cycle effect $(P<0.05)$ and a significant time by stage of the cycle interaction $(P<0.02)$. In contrast, Romanov ewes had only marginally higher FSH concentrations during the follicular compared to the luteal phase. Individual patterns of FSH secretion between animals were highly variable and when each ewe was ranked in one of the three patterns previously defined, there was no effect of the stage of the oestrous cycle on the distribution of Romanov ewes in the three types (Table 3), but there was for Ile-de-France ewes $(P<0.05)$ (Table 3$)$. This further supports a difference in the pattern of FSH secretion between the stages of the cycle in this breed. 
Table 2. Size of follicles and follicular growth rates in two breeds of sheep at two stages of the cycle

\begin{tabular}{ccccc}
\multicolumn{2}{c}{ Romanov } & & \multicolumn{2}{c}{ Ile-de-France } \\
\cline { 1 - 1 } \cline { 5 - 6 } $\begin{array}{c}\text { Follicular } \\
\text { phase }\end{array}$ & Luteal & & Follicular & Luteal \\
$(\mathrm{N}=6)$ & phase & & phase & phase \\
$(\mathrm{N}=6)$ & & $(\mathrm{N}=6)$ & $(\mathrm{N}=6)$ \\
\hline
\end{tabular}

Size of follicles at the 1st laparotomy growing until the 2 nd laparotomy $(\mathrm{mm})$

Growth rates between the 1 st and 2 nd laparotomies ( $\mathrm{mm} /$ day)

Size of follicles at the 2nd laparotomy growing until the 3rd laparotomy $(\mathrm{mm})$

Growth rates between the 2nd and 3rd laparotomies ( $\mathrm{mm} /$ day)

\begin{tabular}{|c|c|c|c|}
\hline $3.9 \pm 0.6^{a}$ & $2.9 \pm 0.5^{b}$ & $3 \cdot 5 \pm 1 \cdot 1$ & $3.4 \pm 0.6$ \\
\hline $0.6 \pm 0.3^{\mathrm{c}}$ & $0.8 \pm 0.4^{d}$ & $0.7 \pm 0.4$ & $0.9 \pm 0.5$ \\
\hline $4.4 \pm 0.9$ & $4 \cdot 2 \pm 1 \cdot 1$ & $4 \cdot 6 \pm 1 \cdot 4$ & $5 \cdot 1 \pm 1 \cdot 2$ \\
\hline $0.7 \pm 0.3$ & $0.5 \pm 0.4$ & $0.3 \pm 0.3$ & $0 \cdot 6 \pm 0.3$ \\
\hline $5 \cdot 8 \pm 0.6$ & $5 \cdot 5 \pm 0 \cdot 8$ & $7 \cdot 1 \pm 1 \cdot 1$ & $6 \cdot 7 \pm 1 \cdot 3$ \\
\hline
\end{tabular}

Maximum follicular diam. measured at the 3rd laparotomy $(\mathrm{mm})$

$5 \cdot 8 \pm 0.6$

$\pm 0 \cdot 8$

$6 \cdot 7 \pm 1 \cdot 3$

Results are means \pm s.d.

Values with different superscripts differ $(P<0.05)$.

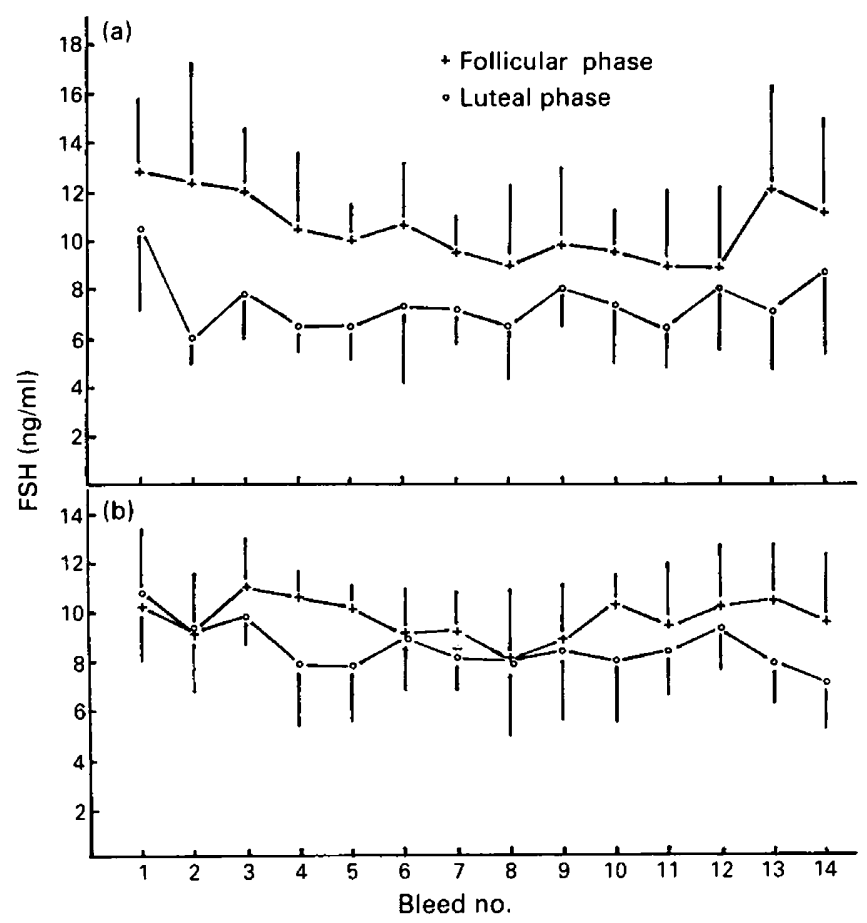

Fig. 1. Changes (mean \pm s.d.) in FSH concentrations in (a) Ile-de-France and (b) Romanov ewes throughout the bleeding period (follicular phase Days 13-17; luteal phase Days 3-7).

\section{Experiment II}

When hCG was injected on Day 16 of the oestrous cycle, it induced the ovulation of $4 \cdot 0 \pm 1 \cdot 3$ and $1.7 \pm 0.5$ follicles in Romanov and Ile-de-France ewes, respectively. When it was given on Day 6 of 
Table 3. Frequency of the different patterns of FSH profiles according to the breed and the physiological status (6 ewes/breed/stage)

\begin{tabular}{lccccc}
\hline & \multicolumn{2}{c}{ Romanov } & & \multicolumn{2}{c}{ Ile-de-France } \\
\cline { 2 - 3 } \cline { 6 - 7 } & $\begin{array}{c}\text { Follicular } \\
\text { phase }\end{array}$ & $\begin{array}{c}\text { Luteal } \\
\text { phase }\end{array}$ & & $\begin{array}{c}\text { Follicular } \\
\text { phase }\end{array}$ & $\begin{array}{c}\text { Luteal } \\
\text { phase }\end{array}$ \\
\hline No feed-back & $3 / 6$ & $2 / 6$ & & $1 / 6$ & $4 / 6$ \\
Feed-back occurring early & $1 / 6$ & $1 / 6$ & & $2 / 6$ & $2 / 6$ \\
Feed-back occurring late & $2 / 6$ & $3 / 6$ & & $3 / 6$ & \\
\hline
\end{tabular}

the cycle, it triggered ovulation in 6/6 Romanov and 4/6 Ile-de-France ewes, with ovulation rates of $4 \cdot 1 \pm 0.7$ and $2 \cdot 2 \pm 0 \cdot 5$, values close to the mean number of mid-cycle corpora lutea seen in these ewes $(4 \cdot 1 \pm 1 \cdot 3$ and $2 \cdot 0 \pm 0 \cdot 6$ for Romanov and Ile-de-France ewes, respectively). The deviation between hCG-induced ovulation rate and the ovulation rate of the previous cycle measured by the number of mid-cycle corpora lutea did not exceed one in 8 out of 10 ewes ovulating.

\section{Experiment III}

After hypophysectomy, 2 Romanov ewes died. Prolactin was undetectable in all blood samples taken after hypophysectomy, indicating that the 6 Ile-de-France and 12 Romanov ewes had been completely hypophysectomized. When injected with 1250 i.u. PMSG and 750 i.u. hCG, 1 Ile-deFrance and 3 Romanov ewes failed to ovulate. The ovulation rate induced by the gonadotrophin treatment in the remainder of the ewes was $1.4 \pm 0.5$ (range 1-2) in 5 Ile-de-France ewes and $5.5 \pm 3.9$ (range 2-11) in 9 Romanov ewes, demonstrating that, when challenged with similar doses of gonadotrophins, the ranking of the two breeds as prolific or non-prolific was retained.

\section{Discussion}

Since the pioneering work of Land \& Falconer (1969), ovulation rate has been thought to be controlled by gonadotrophin concentrations and/or ovarian sensitivity to gonadotrophins. Indeed, in some prolific breeds of sheep, high gonadotrophin concentrations and/or high sensitivity to gonadotrophins have been reported (Lahlou-Kassi et al., 1984; Bindon et al., 1986; McNatty et al., 1987). However, with the discovery that within ovine follicular fluid there may be other regulators of ovarian function (Cahill et al., 1985a, b), the mechanisms controlling ovulation rate in sheep are still unclear. The aim of these present studies was to investigate the role played by gonadotrophin concentrations (mainly FSH) in the differentiation of the ovulatory follicles and ovulation rate within breeds (Exps I and II) and between a prolific (Romanov) and a non-prolific (Ile-de-France) breed of sheep (Exp. III). The results suggest that there is no linear relationship between gonadotrophin concentrations and growth of large follicles to ovulation. Firstly, terminal follicular growth was similar between the follicular and luteal phases, two periods which differ in their hormonal environment. As differences between these two stages in LH and steroid concentrations have been extensively described (Baird, 1978), this study was limited to the measurement of FSH concentrations. Secondly, when given similar amounts of exogenous gonadotrophin hormones after hypophysectomy, Romanov ewes still had a significantly higher ovulation rate than did the Ile-de-France ewes.

Follicular growth is active during the luteal phase as demonstrated by previous histological studies of the ovaries (Turnbull et al., 1977; Lahlou-Kassi \& Mariana, 1984). However, due to the inability of these techniques to investigate the continuum of follicular growth in sheep, no comparative study of the growth of large follicles during the luteal versus the follicular phase of the 
cycle has been undertaken. Ink marking of individual follicles at repeated laparotomies can be used to monitor the dynamics of preovulatory enlargement (Driancourt \& Cahill, 1984). It demonstrated that, whatever the breed, most of the measures of terminal follicular growth (growth rate of the large follicles, number of follicles growing to preovulatory size, maximum size attained) were identical in the early luteal and follicular phases of the oestrous cycle. This is in good agreement with reports on the growth of large follicles throughout the oestrous cycle in cattle (Pierson \& Ginther, 1984; M. A. Driancourt, D. Andrieu \& W. W. Thatcher, unpublished results), and saddle-type mares (Driancourt et al., 1984), but differs from results for women (Gougeon \& Lefevre, 1983), pigs (Dyck, 1983) and pony mares (Driancourt et al., 1984).

While Exp. I demonstrated that follicular growth was morphologically similar during the early luteal and follicular phases of the oestrous cycle in both breeds, Exp. II indicated that this similarity could be extended to the functional ability of the follicles. The similarity in the ovulation rate induced by hCG injection during the follicular and luteal phases in both breeds suggested that the number of follicles with significant numbers of LH receptors on the granulosa cells and possibly the number of $\mathrm{LH}$ receptors per follicle, were unaffected by the different gonadotrophin concentrations observed during the luteal and follicular phases of the cycle, confirming an earlier report (England et al., 1981). Differentiation of LH receptors is thought to result from a joint action of FSH and oestradiol (Richards, 1980). The present study shows that there is some flexibility in the gonadotrophin and steroid concentrations needed to trigger the differentiation of LH receptors. A similar conclusion has been reached for cattle in which luteal-phase follicles have as many LH receptors on the granulosa layer as during the follicular phase (Ireland \& Roche, 1982, 1983) despite dramatic differences in oestradiol content of these follicles (Ireland \& Roche, 1982, 1983) and differences in gonadotrophin concentrations (Walters et al., 1984; Schallenberger et al., 1984). Maintenance of dominance while the other follicles undergo atresia is believed to be linked to the high oestradiol content in follicular fluid of the dominant follicle (Baird \& McNeilly, 1981; Driancourt et al., 1985b). However, while the oestradiol content of the dominant follicle is markedly smaller in the luteal phase than during the follicular phase (McNatty et al., 1981b), its ability to maintain dominance in the luteal phase is striking since it has a steady size from Day 7 to Day 9.

The magnitude of the changes in gonadotrophin concentrations required to stimulate follicular growth is unclear in domestic animals. In humans it has, however, been claimed to be small (Brown, 1978). In this study, differences in FSH concentrations averaging $4 \mathrm{ng} / \mathrm{ml}$ and $1.5 \mathrm{ng} / \mathrm{ml}$ between the follicular and luteal phases were noted in Ile-de-France and Romanov ewes, respectively. The similarity in the pattern of follicular growth, despite these differences in FSH concentrations, may indicate that gonadotrophins are likely to have a permissive action on growth of large follicles. Once their level exceeds a threshold, recruitment and selection of the ovulatory follicles can proceed under the control of the other regulatory mechanisms (Driancourt et al., 1985b). Additional gonadotrophin would not affect these processes until the next threshold is reached when excess gonadotrophins override the other regulatory mechanisms. Such a situation is likely to occur after FSH administration (Wright et al., 1981) or following a follicular fluid treatment (McNeilly, 1984). A similar hypothesis with successive thresholds has been suggested to explain the ovarian response to superovulation (Saumande et al., 1978).

The observation that Romanov and Ile-de-France ewes retained a close to normal ovulation rate even after hypophysectomy and treatment with an identical regimen of exogenous gonadotrophins indicates that some thresholds might be similar between prolific and non-prolific breeds. This is in agreement with a similar study in Booroola and Merino ewes (Fry et al., 1986).

Furthermore, the finding that Romanov as well as Booroola ewes, when hypophysectomized and given the same amounts of exogenous gonadotrophins as their local controls, retain their ovulatory superiority shows that differences in FSH concentrations between these prolific breeds and their controls are only associated with their high prolificacy and are not causing it. This is in good agreement with data demonstrating that the factors responsible for high ovulation rate are present when the hormonal environment is markedly different from the concentrations found during the 
follicular phase: (1) during seasonal anoestrus, the number of oestrogenic follicles is higher in prolific Finns compared to Blackface ewes (Webb \& Gauld, 1984, 1985) and the number of follicles ovulated by hCG is higher in F + Booroola compared to ++ ewes (M. A. Driancourt, J. Thimonier \& J. M. Elsen, unpublished results); (2) before puberty, at 4 months of age, the number of follicles ovulated by hCG is higher in pure Romanov ewe lambs than in Romanov crosses in which it is higher than in Ile-de-France lambs (M. A. Driancourt, unpublished results).

Collectively, these data suggest that, in the breeds studied, quantitative differences in gonadotrophin concentrations do not contribute to the high ovulation rate of the prolific compared to the non-prolific ewes. Nevertheless, since we used acutely hypophysectomized ewes, we cannot discount that gonadotrophin concentrations before the hypophysectomy may be important in 'priming' the ovary for later events. However, as conclusions similar to those reported here have been reached from work with chronic hypophysectomized ewes (Fry et al., 1986), the most likely factors involved in the control of ovulation rate are ovarian sensitivity to gonadotrophins and production or sensitivity to intraovarian regulators of follicular fluid (Ledwitz-Rigby et al., 1981; Hammond et al., 1981; Reichert et al., 1981; DiZerega et al., 1982; Cahill et al., 1985b).

We thank Dr J.P. Ravault for supervision of the prolactin assay; the staff of the surgery in Nouzilly for help; and the E.E.C. for a travel grant to Nouzilly (E.J.).

\section{References}

Baird, D.T. (1978) Pulsatile secretion of LH and ovarian estradiol during the follicular phase of the sheep estrous cycle. Biol. Reprod. 18, 359-364.

Baird, D.T. \& McNeilly, A.S. (1981) Gonadotrophic control of follicular development and function during the oestrous cycle of the ewe. J. Reprod. Fert., Suppl. 30, 119-133.

Baird, D.T., Swanston, I. \& Scaramuzzi, R.J. (1976) Pulsatile release of $\mathrm{LH}$ and secretion of ovarian steroids in sheep during the luteal phase of the estrous cycle. Endocrinology 98, 1490-1496.

Bindon, B.M., Piper, L.R., Cummins, L.J., O'Shea, T., Hillard, M.A., Findlay, J.K. \& Robertson, D. M. (1984) Reproductive endocrinology of prolific sheep: studies of the Booroola Merino. In Genetics of Reproduction in Sheep, pp. 217-236. Eds R. B. Land \& D. W. Robinson. Butterworths, London.

Bindon, B.M., Piper, L.R., Cahill, L.P., Driancourt, M.A. \& O'Shea, T. (1986) Genetic and hormonal factors affecting superovulation. Theriogenology 25, 53-70.

Blanc, M.R. \& Poirier, J.C. (1979) A new homologous radioimmunoassay for ovine follicle stimulating hormone: development and characterization. Annls Biol. anim. Biochim. Biophys. 19, 1001-1026.

Brown, J.B. (1978) Pituitary control of ovarian functionConcepts derived from gonadotrophin therapy. Aust. N.Z. J. Obstet. Gynaec. 18, 47-54.

Cahill, L.P., Saumande, J., Ravault, J.P., Blanc, M., Thimonier, J., Mariana, J.C. \& Mauléon, P. (1981) Hormonal and follicular relationships in ewes of high and low ovulation rates. J. Reprod. Fert. 62, 141-150.

Cahill, L.P., Driancourt, M.A., Chamley, W.A. \& Findlay, J.K. (1985a) Role of intrafollicular regulators and FSH in growth and development of large antral follicles in sheep. J. Reprod. Fert. 75, 599-607.

Cahill, L.P., Clarke, I.J., Cummins, J.T., Driancourt, M.A., Carson, R.S. \& Findlay, J.K. (1985b) An inhibitory action at the ovarian level of ovine follicular fluid on PMSG induced folliculogenesis in hypophysectomized ewes. In Proc. 5th Ovarian Workshop, pp. 35-39, Eds O. Toft \& R. J. Ryan. Ovarian Workshops, Champaign.

Denamur, R. \& Mauléon, P. (1963) Effets de l'hypophysectomie sur la morphologie et l'histologie du corps jaune des ovins. C. r. hebd. Séanc. Acad. Sci., Paris D 257, 264-267.

diZerega, G.S., Goebelsmann, U. \& Nakamura, K. (1982) Identification of protein(s) secreted by the preovulatory ovary which suppresses the follicular response to gonadotrophins. J. clin. Endocr. Metab. 54, 1091-1096.

Driancourt, M.A. \& Cahill, L.P. (1984) Preovulatory follicular events in sheep. J. Reprod. Fert. 71, 205-211.

Driancourt, M.A., Palmer, E. \& Bour, B. (1984) Croissance du follicule préovulatoire chez la jument. In Période Péri-ovulatoire, pp. 55-68. Eds J. SalatBaroux \& C. Thibault. Masson, Paris.

Driancourt, M.A., Cahill, L.P. \& Bindon, B.M. (1985a) Ovarian follicular populations and preovulatory enlargement in Booroola and control Merino ewes. $J$. Reprod. Fert. 73, 93-107.

Driancourt, M.A., Cahill, L.P. \& Gibson, W.R. (1985b) Follicular dynamics throughout the oestrous cycle in sheep. A review. Reprod. Nutr. Develop. 25, $1-15$.

Driancourt, M.A., Gauld, I.K., Terqui, M. \& Webb, R. (1986) Variations in patterns of follicle development in prolific breeds of sheep. J. Reprod. Fert. 78, 565575.

Dufour, J.J., Cahill, L.P. \& Mauléon, P. (1979) Shortand long-term effects of hypophysectomy and unilateral ovariectomy on ovarian follicular populations in sheep. J. Reprod, Fert. 57, 301-309. 
Dyck, G.W. (1983) Postweaning changes in the reproductive tract of the sow. Can. J. Anim. 63, 571-577.

England, B.G., Webb, R. \& Dahmer, M.K. (1981) Follicular steroidogenesis and gonadotropin binding to ovine follicles during the estrous cycle. Endocrinology 109, 881-887.

Fry, R.C., Clarke, I.J., Cummins, J.T., Bindon, B.M., Piper, L.R. \& Cahill, L.P. (1986) Induction of ovulation in hypophysectomized Booroola ewes. Proc. Aust. Soc. Reprod. Biol. 18, Abstr. 48.

Gill, J.L. \& Hafs, H.D. (1971) Analysis of repeated measurements of animals. J. Anim. Sci. 33, 331-336.

Gougeon, A. \& Lefevre, B. (1983) Evolution of the diameter of the largest healthy and atretic follicles during the human menstrual cycle. J. Reprod. Fert. 69, 497-502.

Hammond, J.M., Veldhuis, J.D., Seale, T.W. \& Rechler, M.M. (1981) Intraovarian regulation of granulosa cell replication. Adv. exp. Med. Biol. 147, 341-356.

Ireland, J.J. \& Roche, J.F. (1982) Development of antral follicles in cattle after prostaglandin induced luteolysis: changes in serum hormones, steroids in follicular fluid and gonadotrophin receptors. Endocrinology 111, 2077-2086.

Ireland, J.J. \& Roche, J.F. (1983) Development of nonovulatory antral follicles in heifers: changes in steroids in follicular fluid and receptors for gonadotropins. Endocrinology 112, 150-156.

Kann, G. (1971) Dosage radioimmunologique de la prolactine plasmatique chez les ovins. $C$. $r$. hebd. Séanc. Acad. Sci., Paris D 272, 2808-2811.

Lalhou-Kassi, A. (1982) Contrôle de l'activité ovarienne chez 2 races de brebis marocaines, la D'Man et la Timahdite. Doctorat d'Etat es Sciences Agronomiques, Rabat.

Lalhou-Kassi, A. \& Mariana, J.C. (1984) Ovarian follicular growth during the oestrous cycle in two breeds of ewes of different ovulation rates, the D'Man and Timahdite. J. Reprod. Fert. 72, 301-310.

Lalhou-Kassi, A., Schams, D. \& Glatzel, P. (1984) Plasma gonadotrophin concentration during the oestrous cycle and after ovariectomy in two breeds of sheep with low and high fecundity. J. Reprod. Fert. 70, 165-173.

Land, R.B. \& Falconer, D.S. (1969) Genetic studies of ovulation rate in the mouse. Genet. Res. 13, 25-46.

Ledwitz-Rigby, L., Rigby, B.W., Ling, S.Y., Stewart, L. \& McLean, M. (1981) Stimulation of granulosa cell maturation by follicular fluid. Adv. exp. Med. Biol. 147, 331-341.

McNatty, K.P., Gibb, M., Dobson, C. \& Thurley, D.C. (1981a) Evidence that changes in luteinizing hormone secretion regulate the growth of the preovulatory follicle in the ewe. J. Endocr. 90, 375-389.

McNatty, K.P., Gibb, M., Dobson, C., Thurley, D.C. \& Findlay, J.K. (1981b) Changes in the concentrations of gonadotrophic and steroidal hormones in the antral fluid of ovarian follicles throughout the estrous cycle of the sheep. Aust. J. biol. Sci. 34, 67-80.

McNatty, K.P., Hudson, N., Henderson, K.M., Gibb, M., Morrison, L., Ball, K. \& Smith, P. (1987) Differences in gonadotrophin concentrations and pituitary responsiveness to $\mathrm{GnRH}$ between Booroola ewes which were homozygous (FF), heterozygous $(\mathrm{F}+)$ and non-carriers $(++)$ of a major gene influencing their ovulation rate. J. Reprod. Fert. 80, 577-588.
McNeilly, A.S. (1984) Changes in FSH and the pulsatile secretion of $\mathrm{LH}$ during the delay in oestrus induced by treatment of ewes with bovine follicular fluid. $J$. Reprod. Fert. 72, 165-172.

McNeilly, A.S., Jonassen, J.A. \& Fraser, H.M. (1986) Suppression of follicular development after chronic LHRH immunoneutralization in the ewe. J. Reprod. Fert. 76, 481-490.

Miller, K.F., Nordheim, E.V. \& Ginther, O.J. (1981) Periodic fluctuations in FSH concentrations during the ovine estrous cycle. Theriogenology 16, 669-679.

Oldham, C.M. \& Lindsay, D.R. (1980) Laparoscopy in the ewe: a photographic record of the ovarian activity of ewes experiencing normal or abnormal oestrous cycles. Anim. Reprod. Sci. 3, 119-124.

Pierson, R.A. \& Ginther, O.J. (1984) Ultrasonography of the bovine ovary. Theriogenology 21, 495-504.

Reichert, L.E., Jr, Sanzo, M.A., Fletcher, P.W., Dias, J.A. \& Lee, C.Y. (1981) Properties of folllicle stimulating hormone binding inhibitors found in physiological fluids. Adv. exp. Med. Biol. 147, 135-144.

Richards, J.S. (1980) Maturation of ovarian follicles. Actions and interactions of pituitary and ovarian hormones on follicle cell differentiation. Physiol. Rev. 60, 51-89.

Saumande, J., Chupin, D., Mariana, J.C., Ortavant, R. \& Mauléon, P. (1978) Factors affecting the variability of ovulation rates after PMSG stimulation. In Control of Reproduction in the Cow, pp. 195-225. Ed. J. M. Sreenan. Martinus Nijhoff, The Hague.

Schallenberger, E., Schams, D., Bullerman, B. \& Walters, D.L. (1984) Pulsatile secretion of gonadotrophins, ovarian steroids and ovarian oxytocin during prostaglandin-induced regression of the corpus luteum in the cow. $J$. Reprod. Fert. 71, 493-501.

Siegel, S. (1956) Non-parametric Statistics for the Behavioral Sciences. McGraw Hill, New York.

Turnbull, K.E., Braden, A.W.H. \& Mattner, P.E. (1977) The pattern of follicular growth and atresia in the ovine ovary. Aust. J. biol. Sci. 30, 229-241.

Walters, D.L., Schams, D. \& Schallenberger, E. (1984) Pulsatile secretion of gonadotrophins, ovarian steroids and ovarian oxytocin during the luteal phase of the cow. J. Reprod. Fert. 71, 479-491.

Webb, R. \& England, B.G. (1982) Identification of the ovulatory follicle in the ewe: associated changes in follicle size, thecal and granulosa cell luteinizing hormone receptors, antral fluid steroids and circulating hormones during the preovulatory pefiod. Endocrinology 110, 873-881.

Webb, R. \& Gauld, I.K. (1984) Final maturation of the preovulatory follicle in the ewe. In Période Périovulatoire, pp. 21-32. Eds J. Salat Baroux \& C. Thibault. Masson, Paris.

Webb, R. \& Gauld, I.K. (1985) Folliculogenesis in sheep: control of ovulation rate. In Genetics of Reproduction in Sheep, pp. 261-275. Eds R. B. Land \& D. W. Robinson. Butterworths, London.

Wright, R.W., Bondioli, K., Grammer, J., Kuzan, F. \& Menino, A. (1981) FSH or FSH plus LH superovulation in ewes following estrus synchronisation with medoxyprogesterone acetate pessaries. $J$. Anim. Sci. 52, 115-118. 